\title{
The Effect of Managerial Ownership, Profitability, Company Size on the Integrity of Financial Statements at Plantation Companies
}

Feber Sormin

${ }^{1}$ Universitas Mercu Buana, Jakarta, Indonesia

DOI: $10.36348 /$ sjef.2021.v05i04.004 | Received: 08.03.2021 | Accepted: 05.04.2021 | Published: 07.04 .2021

*Corresponding author: Feber Sormin

\section{Abstract}

This study aims to determine the integrity of the financial statements of plantation companies listed on the Indonesia Stock Exchange 2017-2020. This study began to observe information on cases of disclosure of corporate financial statements that are published and do not meet the characteristics of accounting standards in several business sectors which are thought to be influenced by various factors such as managerial ownership, profitability ratios, and company size. This study used quantitative methods with multiple regression analysis through statistical data analysis software SPSS. The data used is secondary data which is collected through literature review and downloading the issuer's financial statements via IDX.co.id. This study found a negative effect of managerial ownership and firm size on the integrity of financial statements, while the effect of profitability was not found. This finding explains the function of managers as agents and at the same time as a principle of providing great opportunities for managers in making policies that benefit themselves so that the integrity of financial reports is low, as well as the fact that the level of company prosperity encourages management to take policies that have an impact on low financial statement's integrity.

Keywords: Managerial Ownership, Profitability, Company Size, Integrity of Financial Statements.

Copyright (C) 2021 The Author(s): This is an open-access article distributed under the terms of the Creative Commons Attribution 4.0 International License (CC BY-NC 4.0) which permits unrestricted use, distribution, and reproduction in any medium for non-commercial use provided the original author and source are credited.

\section{INTRODUCTION}

Quality or integrity financial statement information will influence the attitude of providers of capital and other stakeholders in investing, providing credit, or other parties. Disclosure of information that is irrelevant or contains material errors by management in the financial statements certainly affects the integrity of the financial statements as accountability to the economic decision-maker. The freedom to apply accounting methods following the principles of accounting standards will influence managers in earnings management to demonstrate company performance. Reliability, transparency, and uniformity of the financial reporting process allow investors to make smart decisions [1].

Some financial report fraud has occurred in almost all countries including Indonesia, one of which is the case of the GOOL plantation company which resulted in the halt of trading in its shares in 2019 [2]. The fact is that there are still many issuers whose seriousness and integrity are still being questioned in carrying out their obligations under applicable regulations both on the stock exchange and government regulations so that there are 25 issuers who are subject to fines for being late in carrying out their obligation to publish financial reports [3]. While the integrity of financial statements is needed by users of financial statements because with high integrity, the quality of financial reports is guaranteed and helps investors to help predict future earnings [4] which in turn has an impact on the value of the company on the stock exchange [5].

Several studies have analyzed the factors that influence the integrity of financial statements. Managerial ownership was found to have a positive influence on the integrity of financial statements [6] because, with a high level of ownership, managers have a high responsibility for the quality of financial statements so that the level of integrity of financial statement information is maintained. Even so, Sauqi, et al. [7] found the opposite where the negative influence of managerial ownership on the integrity of financial statements is due to a conflict of interest so that company performance looks good, thus sacrificing the integrity of financial statements.

The level of profitability and company size was also found to influence the integrity of financial 
Feber Sormin., Saudi J Econ Fin, Apr, 2021; 5(4): 160-163

statements [8] because changes in company profits and assets encourage management to take actions that affect the integrity of financial statements so that company profits and assets are more sustainable. Even so, the results of other studies do not find an effect on profitability [9] and company size [6].

In the case of financial report fraud that reflects the low integrity of financial statements as well as the results of previous research, this study aims to analyze the effect of managerial ownership, profitability, and company size on the integrity of financial statements of plantation companies listed on the Indonesia Stock Exchange in the 2017-2020 period.

\section{LITERATURE REVIEW Theoretical Framework}

Jensen \& Meckling [10] define agency theory as the relationship between agent and principal. In an agency relationship, there is a contract where one or more people order other people to perform a service on behalf of the principal and authorizes the agent to make the best decisions for the principal. The conflict of interest between the principal and agent is called the agency problem.

The relationship between agency theory on the Integrity of Financial Statements is implemented, each party involved will take a series of actions that benefit their respective parties, such as the management who is most aware of the condition of the company, of course, will try to inform the company's performance properly to the owner through quality financial statement information so that owners or investors can trust management to continue the business of the company. The drive for good company performance results is one of the triggers for management to carry out any practice to maintain its existence in the company. Through the role of utilizing managerial ownership of shares, conditions of profitability and showing the development of the size of the managerial company, hope to maintain the integrity of the company's financial statements properly.

\section{Conceptual Framework and Hypothesis Development}

Managerial ownership is the percentage of share ownership owned by directors, managers, and the board of commissioners. The presence of company owners in the management of the company creates a conflict of interest so that the policies taken benefit the company owners as well as the internal management of the company. Savero, et al. [11] found the effect of managerial ownership on the integrity of financial statements.

H1. Managerial ownership has an impact on the integrity of financial statements
The profitability ratio shows the company's ability to earn profits [12]. With this ratio, management uses its resources in the procedures for preparing financial statements so that the integrity of financial statements is low due to internal conflicts of interest. In his research, Himawan [13] found the effect of profitability ratios on the integrity of financial statements.

H2. Profitability has an impact on the integrity of financial statements

The size of the company indicates the level of prosperity of the company because it is seen from the number of asset values, market values, and others. This level of prosperity encourages management to do things that are normal or unreasonable, both operationally and in the procedures for preparing financial statements, thus impacting the integrity of the financial statements. Gayatri, et al. [8] found a significant effect of company size on the integrity of financial statements.

H3. Company size has an impact on the integrity of financial statements

\section{METHODOLOGY \\ Population and Sample}

The unit of analysis for this research is plantation companies listed on the Indonesia Stock Exchange for the period 2017-2020 as a population, while the research sample was obtained by using the purposive sampling method with criteria 1) plantation companies listed on the Indonesia Stock Exchange, and 2) having complete research data. A total of 21 companies were sampled in this study, with a total of 63 data.

\section{Operational Variable}

The integrity of financial statements is the dependent variable of this study. Modifying the measurement of book market value used by Budiharjo, et al. [6], this study measures the integrity of financial statements by subtracting the current stock price from last year's stock price then dividing the current stock price.

Adopting Dewi \& Suryanawa's [14] research, managerial ownership is measured by dividing the number of shares owned by managers by the number of company shares. Meanwhile, profitability in this study is measured using Return on Assets [15]. The size of the company represents the level of prosperity of a company. Total Sales are used in this study to calculate the size of the company.

\section{Hypothesis Testing Method}

The 63 data analyzed in this study found the problem of classical assumptions so that data outliers were eliminated and 36 data was left. After the data passes the classical assumption tests such as normality 
Feber Sormin., Saudi J Econ Fin, Apr, 2021; 5(4): 160-163

test, heteroscedasticity test, multicollinearity test, and classical assumption test, then the Fit test is analyzed which produces a fairly good value. As for the t-test, the following results were found:

Table-1: Hypothesis Test

\begin{tabular}{|l|l|ll|}
\hline \multirow{2}{*}{ Variable } & INTEGRITY (Y) & & \\
\cline { 2 - 5 } & Unstandardized B & Sig & \\
\hline MAN (X1) & -0.005 & 0.008 & $* * *$ \\
\hline ROA (X2) & 0.313 & 0.650 & \\
\hline SIZE (X3) & -0.116 & 0.019 & $* *$ \\
\hline N & 36 & & \\
\hline
\end{tabular}

Table 1 shows that managerial ownership has a significant effect on the integrity of financial statements, these results indicate that the first hypothesis is accepted. With an unstandardized value of -0.005 , it shows that managerial ownership hurts the integrity of financial statements.

Table 1 also explains that profitability does not affect the integrity of financial statements, so hypothesis 2 is rejected. Table 1 also finds a significant effect of company size on the integrity of financial statements, so hypothesis 3 is accepted. With an unstandardized value of -0.116 , it shows that company size harms the integrity of financial statements.

\section{RESULT AND DISCUSSION}

This study found a significant negative effect of managerial ownership on the integrity of financial statements. With the large number of shares owned by the manager, the manager's internal conflict of interest becomes high so that it has an impact on the financial report preparation process and the integrity of the financial statements is low. Managers who are also company owners find it easier to adopt policies in the procedures for preparing financial reports for personal purposes. The finding of the effect of managerial ownership on the integrity of financial statements is in line with the research of Savero, et al. [11] and Sauqi, et al. [7].

Similar results are also found on the effect of company size on the integrity of financial statements. With a fairly high level of prosperity, the fact is that management is still motivated to carry out procedures for preparing financial statements that lack integrity so that the integrity of financial statements is low. The finding of the influence of company size on the integrity of financial statements is in line with the research of Gayatri, et al. [8, 16].

This study did not find any effect of profitability on the integrity of financial statements. This indicates that the level of corporate profits in the current year does not have a sufficient impact on management in the process of preparing financial statements, including in assessing the integrity of financial statements.

\section{CONCLUSIONS \& SUGESTIONS}

The results of this study found the following:

1. Managerial ownership harms the integrity of financial statements. These results provide important information for investors in assessing the integrity of financial statements.

2. Profitability does not affect the integrity of financial statements. Future studies can analyze other variables that may have a strong influence or other units of analysis that may have different results.

3. Company size hurts the integrity of financial statements. These results can also be important information for investors in assessing the integrity of the issuer's financial statements in predicting future earnings.

\section{ACKNOWLEDGMENT}

This research was supported by the Mercu Buana University research center and the KKR Accounting of Mercu Buana University.

\section{REFERENCES}

1. Rezaee, Z. (2005). Causes Consecuences, and Deterence of Financial Statement Fraud. Critical Perspectives on Accounting, 16(3). 277-298. https://doi.org/10.1016/S1045-2354(03)00072-8

2. Yazid, M. (2019). Lepas dari TPS Good, GOLL didenda BEI karena Lapkeu. CNBC Indonesia, dipublikasi tgl 1 Juli 2019, Jam 11:43Wib, diakses $\begin{array}{llll}\text { pada } & \text { tgl } & 13 & \text { Januari }\end{array}$ https://www.cnbcindonesia.com/market/201907011 11703-17-81795/lepas-dari-tps-food-goll-didendabei-karena-lapkeu

3. Toarik, M. (2020). Belum setor Laporan Keuangan, 25 Emiten kena sanksi Denda BEI. Investor Daily, Publikasi tgl 7 November 2020 jam 11:25 WIB. diakses pada tgl 13 Januari 2021. https://investor.id/market-and-corporate/belumsetor-laporan-keuangan-25-emiten-kena-sanksidenda-bei

4. Tarmidi, D., Murwaningsari, E., Umar, H., \& Mayangsari, S. (2020). The Influence of Tax Compliance and Earnings Quality on Financial Performance (Evidence from Indonesia and Thailand). International Journal of Emerging Trends in Social Science, 8(2), 70-74. https://doi.org/10.20448/2001.82.70.74

5. Tarmidi, D., \& Murwaningsari, E. (2019). The Influence of Earnings Management and Tax Planning on Firm Value with Audit Quality as Moderating Variable. Research Journal of Finance and Accounting, 10(4), 49-58. DOI: 10.7176/RJFA

6. Budiharjo, R., Supriatiningsih \& Irawan, A. (2020). The Influence Of Institutional Ownership, Managerial Ownership, Leverage And Firm Sizes 
Feber Sormin., Saudi J Econ Fin, Apr, 2021; 5(4): 160-163

On Integrity Of Financial Statements. Quest Journals Journal of Software Engineering and Simulation, 6(3), 30-37.

7. Sauqi, A., Akram, A., \& Pituringsih. E. (2017). The Effect Of Corporate Governance Mechanism, Auditor Independence, And Audit Quality To Integrity Of Financial Statements. International Conference and Call for Papers, 1456-1475

8. Gayatri, I. A. S., \& Suputra, I. D. G. D. (2013). Pengaruh Corporate Governance, Ukuran Perusahaan dan Leverage Terhadap Integritas Laporan Keuangan. E-Jurnal Akuntansi Universitas Udayana, 5(2), 345-360.

9. Harun, A., Askandar, N. S., \& Junaidi, J. (2020). Analisis Pengaruh Corporate Social Responsibility (CSR), Profitabilitas, Kinerja Perusahaan dan Kualitas audit terhadap Integritas Laporan Keuangan (Studi empiris pada perusahaan Manufaktur yang terdaftar di BEI tahun 20162018). Jurnal Ilmiah Riset Akuntansi, 9(05), 98113.

10. Jensen, M. C., \& Meckling, W. H. (1976). Theory of The Firm: Managerial Behavior, Agency Costs and Ownership Structure. Journal of Financial Economics, 3(4), 305-360.

11. Savero, D.A., Nasir, A., \& Safitri, D. (2017). Pengaruh Komisaris Independen, Komite Audit, Kepemilikan Institusional dan Kepemilikan Manajerial Terhadap Integritas Laporan Keuangan
(Studi Empiris Pada Perusahaan Manufaktur yang Terdaftar di Bursa Efek Indonesia Tahun 20122014). JOM Fekon, 4(1), 75-89

12. Kasmir. (2016). Analisa Laporan Keuangan, Cetakan Kesembilan. Jakarta: PT. Rajagrafindo Persada.

13. Himawan, F.A. (2019). Analisis Pengaruh Good Corporate Governance, Profitabilitas dan Leverage Terhadap Integritas Laporan Keuangan dengan Moderasi Kualitas Audit pada Perusahaan Manufaktur yang Terdapat di Bursa Efek Indonesia Periode 2013-2017. ESENSI: Jurnal Manajemen Bisnis, 22(3), 289-311. Retrieved from https://ibn.ejournal.id/index.php/ESENSI/article/view/173

14. Dewi, N. K. S. L., \& Suryanawa, I. K. (2014). Pengaruh Struktur Kepemilikan manajerial, Leverage, dan Financial Distress Terhadap Konservatisme Akuntansi. E-Jurnal Akuntansi Universitas Udayana, 7(1), 223-234.

15. Hery (2015). Analisis Kinerja Manajemen. Jakarta: Kompas Gramedia

16. Ariyani, N. N. T. D., \& Budiartha, I. K. (2014). Pengaruh Profitabilitas, Ukuran Perusahaan, Kompleksitas Operasi Perusahaan Dan Reputasi KAP Terhadap Audit Report Lag Pada Perusahaan Manufaktur. E-Jurnal Akuntansi Universitas Udayana, 8(2), 217-230. 